\section{DANDELION \\ postgraduate arts journal \& research network}

VOLUME 8 NUMBER I SUMMER 2017
MARA ARTS (@Mara_Arts) is a doctoral student in the Department of Film, Media and Cultural Studies at Birkbeck, University of London. Her research focuses on the representation of London nightlife in British cinema and popular press of the interwar period. She is also a founding member of the Ephemeral Cities research group, where she writes about visual representations of urban space.

\title{
Mutants: Toby Litt on Writing and Literature
}

\author{
Mara Arts
}

TOBY LITT IS PRIMARILY KNOWN AS AN AUTHOR OF A TYPE OF FICTION HIS PUBLISHER DESCRIBES AS 'HIP-LIT'. In addition to his work as a writer, Litt also teaches on the MA Creative Writing at Birkbeck, University of London. His latest fiction publication is the short story collection Life Like (Seagull Books, 2014).

Litt's most recent book, however, is a collection of non-fiction works. Mutants: Selected Essays (Seagull Books, 2016) brings together previously published works and transcripts of lectures Litt has delivered. Their original sites of creation, listed at the back of the volume, vary from edited volumes to websites to university lectures. All the texts, twenty-six in total, were originally produced between 2000 and 2014: the first half of the essays are grouped in a section titled 'What I think'; the second half sit in a section named '\& How I came to think it'.

The ambiguity of the volume's title and the range of its content may lead prospective readers to expect a certain randomness in the topics selected. Yet Mutants is a remarkably cohesive selection of pieces about writing and literature. The order of the essays is clearly well thought-out, with many sections building on or referring back to what has gone before. Litt explores the nature and identity of Literature with a capital L, the role of Literature in the digital age, and what the differences are between bad, competent, and good writers. Authors of fiction can certainly gain insights from Litt's experience, but the volume also allows those who engage in other types of writing, such as academic research, to ask new questions about their practices. 
By making his own thought process the primary way of ordering the contents, Litt gives a clear signal that there is a personal element to this collection. Additionally, in a number of the essays, he speaks about aspects of his personal life, including his childhood and upbringing, ${ }^{1}$ his work at Birkbeck, ${ }^{2}$ and his partner. ${ }^{3}$ This creates a familiar atmosphere between reader and writer, and signals that a text can never be totally separated from its scribe. Yet in the arguments Litt makes about the how and the why of writing, he simultaneously reminds the reader that an author never reveals more than he or she wants.

Despite the brief excursions into Litt's private life, the majority of Mutants discuss some of the big issues facing twenty-first-century writers. Throughout the essays, Litt clearly places his own work in a history of literature, frequently referring back to Joyce, Woolf, Beckett, James and Austen to illustrate arguments. Unsurprisingly, then, he stresses the importance of the literary tradition, and in several essays he voices an explicit appreciation of the 'old masters' over contemporary writers. ${ }^{4}$ In Litt's view, technological advancements can be destructive to good writing. For instance, he elaborates on the 'Curse of the Cursor' - his name for the way writing in a word processer encourages cutting and pasting of words and sentences without considering the effect of this on the rest of the text. ${ }^{5}$

Near the end of the volume, Litt explores the particular challenges of writing about the city, in two essays: 'Here is London, Giddy London' and 'Writing Twenty-First-Century London'. ${ }^{6}$ In particular, he explores the concepts of simultaneity and multiplicity by considering how to depict a large number of events happening to different people, at the same time. He likens this to the paintings and drawings of William Hogarth, who is famous for his detailed crowd scenes. ${ }^{7}$ Elsewhere, Litt compares literary fiction to cinema, arguing that the way film collapses time and space through editing (and therefore manipulates simultaneity) has had a perhaps irreversible effect on audiences' perceptions, which also affect how they read. ${ }^{8}$ Through these excursions into other media, Litt places literature in a larger framework, but he makes it clear that for him, literature is the most versatile and productive form of art.

Aside from drawing parallels with other types of creative work, Litt also refers to quantum physics several times throughout Mutants. ${ }^{9}$ These topics (technology, physics, painting, film) may seem disconnected but they are not, as the overall theme of Mutants reveals itself to be the relationship between writing and time. Writing happens 'in the present' and an author's output is affected by how they write, as well as by which temporalities he or she consumes throughout the day. ${ }^{10}$ Fiction writing has an affinity to time travel, in the way it depicts different things happening at different times. Writing takes time, but also creates it.

Litt argues that it is imperative for a writer to consider their relationship with time. He places time at the forefront in the essay 'STORGY', the penultimate piece in the first half of the work. ${ }^{11}$ It is a transcript of an interview published on the Storgy website (storgy.com, an online literary short story magazine). In it, the temporal relationship between question and answer breaks down, bringing it starkly to the reader's attention.

The final question about time is one posed to the reader: how are they going to use their time when studying this book? As with any collection of pieces, one can read it cover to cover, or select chapters randomly. I did the former, which allowed me to identify parallels and links between pieces. Those readers who may want to use Mutants as a more practical guide to thinking about writing may benefit more from a selective approach. Anyone interested in writing, reading, or both, will be able to get something useful out of this work. 
Readers who want to learn more about Toby Litt can visit his blog: www.tobylitt.com.

\section{Birkbeck College, University of London}

\section{Notes}

Toby Litt, Mutants: Selected Essays (London: Seagull Books, 2016), p. 49.

Ibid., p. 74.

Ibid., p. 246.

Ibid., p. 276.

Ibid., pp. 54-57. I am painfully aware that I am writing this on a laptop, selfconsciously second-guessing every word I write.

Ibid., pp. 258-274 and 275-290.

Ibid., pp. 258-274.

Ibid., pp. 228-244.

Ibid., p. 85.

Ibid., p. 221.

Ibid., pp. 154-158.

\section{Works Cited}

Litt, Toby, Mutants: Selected Essays (London: Seagull Books, 2016) 